\title{
Assessment of Plant Diversity of Selected Forest Sites of Aurangabad District of Bihar
}

\author{
A. Chandra*, H. B. Naithani, P. K. Verma, J. Saxena, R. Saini and S. Kishwan \\ Forest Botany Division, Forest Research Institute, Dehradun- 248006, India \\ *Corresponding author
}

\begin{abstract}
A B S T R A C T
Keywords

Important Value Index, Diversity

Index, Species

Richness, Evenness

Article Info

Accepted:

07 January 2021

Available Online:

10 February 2021

Plant diversity of natural forest selected sites of Aurangabad district of Bihar was assessed. Study was carried out in twelve sites. A total of 126 species belonging to 49 families and 104 genera were reported from all twelve sites. Different indices such as Important Value Index (IVI), Species richness, Shannon Wiener index, Concentration of dominance and Evenness were estimated. For different sites highest IVI for tree was reported (Ficus mollis (2 sites), Acacia catechu, Diospyros melanoxylon var. tupra, Azadirachta indica, Lagerstroemia parviflora (2 sites), Strychnos potatorum, Butea monosperma, Lannea coromandelica and Diopspyros melanoxylon ). Study reveals that Mahulan and pathra forest sites are more diverse forest sites in the Aurangabad district. Study also reveals that Lantana camara var. aculeata an invasive showed its presence in the area, it can adversely impact the indigenous species in future.
\end{abstract}

\section{Introduction}

Vegetation is primary source for energy which transfer to other trophic levels. Environment of an area effects the vegetation of an ecosystem (Billings, 1952). Structure and function of plant community can be understood by phyto-sociological study of the area. It explains and predicts pattern in a meaningful manner (Braun Blanquet, 1932, Odum, 1971). Therefore, for proper understanding of plant diversity of any area, phyto-sociology aspects should be thoroughly studied. Biodiversity in wild state has its far reaching importance as species have diverse genotypes which can further be exploited.
Forest are storehouse of the biodiversity, therefore, it is need of the hour to assess and conserve the forest biodiversity. However, owing to burgeoning population coupled with rapid industrialization plant resources are under tremendous pressure. It has resulted decline of plant diversity in forest ecosystem. Convention of Biological Diversity also asserted the need of regular inventorization and monitoring of biodiversity for sustainable utilization. The state of Bihar has recorded forest area of $6877 \mathrm{~km}^{2}$, which is $7.3 \%$ of its geographical area. The Reserve, Protected and Unclassified Forests are $693 \mathrm{~km}^{2}, 6183 \mathrm{~km}^{2}$ and $1 \mathrm{~km}^{2}$ respectively. The forest cover in the state is $7306 \mathrm{~km}^{2}$ which is $7.76 \%$ of the 
total geographical area of the state. On the basis of density classes, $333.13 \mathrm{~km}^{2}$ is under very dense forest, $3280.32 \mathrm{~km}^{2}$ under moderately dense forests and $3692.54 \mathrm{~km}^{2}$ under open forest. Aurangabad is one of the 38 districts of Bihar. The district has geographical area of $3305 \mathrm{~km}^{2}$. The district has two sub-divisions namely Aurangabad and Daudnagar and 11 blocks namely, Madanpur, Kutumbba, Daudnagar, Aurangabad, Barun, Obra, Deo, Nabinagar, Haspura, Goh and Rafiganj. The forest cover in the Aurangabad district is $156.76 \mathrm{~km}^{2}$ which is $4.74 \%$ of the total geographical area of the state. On the basis of density classes, $62.26 \mathrm{~km}^{2}$ under moderately dense forests and $94.50 \mathrm{~km}^{2}$ under open forest. There is no very dense forest in the Aurangabad district (FSI, 2019).

Bihar state has been extensively survey for its floral wealth by various workers in the past (Anderson, 1863; Hooker, 1872-1897; Wood, 1903; Haines, 1921-1925: Mukhrjee, 1947; Mooney, 1950 Paul, 1973; Biswas and Maheshshwari, 1980; Bhatacharya and Sarkar, 1998, Singh et al., 2001 etc.). Qualitative status cannot provide the dynamics of vegetation of the area, therefore, quantitative status should be worked out. Diversity indices for various forests ha been reported by several workers (Whittakar, 1965; Risser and Rice, 1971; Ralhan et al., 1982; Knight, 1963). However, till date no work has been reported on different diversity indices of different sites of the region. Therefore, in the present study efforts have been made to assess the different sites for comparison of different sites.

\section{Materials and Methods}

\section{Study site, survey and vegetative data}

Study was conducted at the Aurangabad district of Bihar. The district with a geographical area of $3305 \mathrm{~km}^{2}$ between the longitudes of $84^{\circ} 00^{\prime}-84^{\circ} 45^{\prime} \mathrm{E}$ and latitudes of $24^{0} 30^{\prime}-25^{0} 15^{\prime} \mathrm{N}$ is located in the South Bihar Plains (SBP) and constitute a part of the marginal alluvial plains of Ganga Basin.

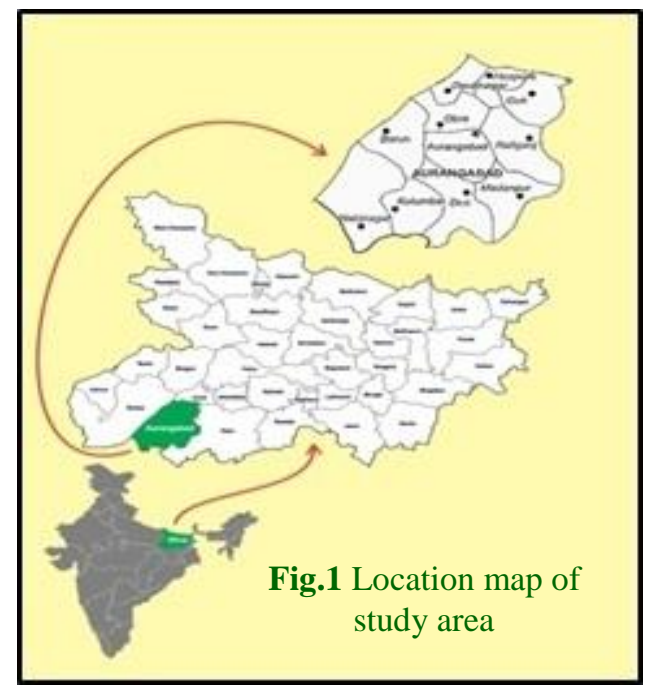

Twelve random forest sites were selected for the vegetation analysis. Random coordinating points were provided by the GIS cell of the Forest Research Institute, Dehradun for collection of vegetative data. Details of sites is given in Table 1. Quantitative analysis of vegetation for frequency, density and dominance was calculated following Mishra (1968). 10 quadrats were randomly laid in each site. Quadrate size of $10 \times 10 \mathrm{~m}, 3 \times 3 \mathrm{~m}$ and $1 \times 1 \mathrm{~m}$ was kept for trees, shrubs and herbs respectively. In each quadrat, g.b.h. (girth at breast height at $1.37 \mathrm{~m}$ above ground level) of each tree was measured and recoded individually. In case of herb and shrub, diameter was measured $2.5 \mathrm{~cm}$ above ground level. Species were identified with the help of concerned floras and matched with DD Herbarium specimens. Plant nomenclature was updated as per the plant list website (www.theplantlist.com.). Values of Relative frequency, density and dominance were summed to get Importance Value Index (IVI). Different biodiversity indices were estimated as given below: 
S= Species Richness

Total number of species

Shannon-Wiener information function (Shannon \& Wiener, 1963) was calculated using the formula:

$\mathrm{H}=-\sum$ pi ln pi

Where pi is $(\mathrm{Ni} / \mathrm{N}), \quad \mathrm{Ni}=$ Number of individuals of species $\mathrm{i}$ and $\mathrm{N}=$ Total number of individuals of all the species.

Concentration of dominance (cd) was measured by Simpson Index (Simpson, 1949).

$\mathrm{Cd}=\sum(\mathrm{pi})^{2}$

Pielou's evenness index (Pielou, 1966) was calculated using formula:

$J=H^{\prime} / \ln (S)$

Where $H^{\prime}$ is Shannon Weiner diversity and $S$ is the total number of species

\section{Results and Discussion}

In the present study, a total of 126 species belonging to 49 families and 104 genera were reported from all twelve sites. Biggest family was Fabaceae (12 spp.) followed by Rubiaceae and Poaceae (6 spp. each), Asteraceae, Rhamnaceae, Malvaceae and Acanthaceae (5 spp. each), Moraceae (4 spp.) etc. Plant species vary in their responses to environmental factors. A given species will have a unique set of tolerances to environmental variables, such as light, temperature, moisture, and nutrients. The status of a species is an important indicator for its conservation and sustainable utilization. Importance Value Index (IVI) is a measure of how dominant a species is in a given forest area. IVI was estimated for tree, shrubby and herbaceous layers. In tree layer, on the basis of IVI most dominant species in different sites is shown in Fig.2. Among different sites, highest IVI was reported for Azadirachta indica (229.58, Site-IV) followed by Lagerstroemia parviflora (211.18, siteXI), Acacia catechu (186.57, Site II), Diospyros melanoxylon (153.72, Site-XII) Strychnos potatorum (128.26, Site-VIII), etc. In case of shrubby layer, highest IVI was estimated for Casearia tomentosa (-119.7, site-I) and lowest for Holarrhena pubescens (42.16, site-X) In herbaceous layer, highest IVI reported for Hyptis suaveolens (129.33, Site-VIII ) and lowest for Tridex procumbens (55.58, Site- II).

Diversity indices aim to describe general properties of communities that allow us to compare different regions and taxa. Diversity indices viz., Shannon-Wiener Diversity Index $(\mathrm{H})$, Concentration of Dominance (cd), Evenness (E) and Species Richness (SR) for different growth forms at different sites of Aurangabad district is presented in Table 1. Higher value of species richness indicates higher diversity of species. In the tree layer, Mahulan site showed highest Species Richness (SR) of 23 species followed by Pathra Beat (18 spp.), Bheli Bandh (17 spp.) etc. and lowest was recorded for Salaya Forest (2 spp.) while Unga Forestlacks tree growth in the area. In case of shrubby layer, highest Species Richness (SR) value was found in Pathra Beat (20 spp.), followed by Mahulan (18 spp.), Eroura (14 spp.) etc. and lowest was in Nima Forestand Pirthu Forest (6 spp. each). Herbaceous layer had highest Species Richness (SR) in Mahulan (29 spp.), followed by Pathra Beat (24 spp.), Badam Forest (19 spp.), Nima Forest and Peeghliya Forest (Each with 16 spp.) etc. and lowest value was found in Unga Forest (5 spp.). The higher value of Diversity Index $(\mathrm{H})$ indicates the variability in the type of species and heterogeneity in communities whereas lesser value points to homogeneity in the community (Fig. 3 and 4). 
Table.1 Diversity indices for different growth forms at different sites of Aurangabad District of Bihar

\begin{tabular}{|c|c|c|c|c|c|c|c|c|c|c|c|c|c|}
\hline \multirow{2}{*}{$\begin{array}{l}\text { Site } \\
\text { no. }\end{array}$} & \multirow[t]{2}{*}{ Sites Name } & \multicolumn{4}{|c|}{ Tree Layer } & \multicolumn{4}{|c|}{ Shrubby Layer } & \multicolumn{4}{|c|}{ Herbaceous Layer } \\
\hline & & SR & $\mathbf{H}$ & cd & $\mathbf{E}$ & SR & $\mathbf{H}$ & cd & $\mathbf{E}$ & SR & $\mathbf{H}$ & cd & $\mathbf{E}$ \\
\hline I. & Badam, Madanpur Range & 7 & 1.781 & 0.186 & 1.107 & 9 & 1.669 & 0.257 & 0.760 & 19 & 2.111 & 0.216 & 0.216 \\
\hline II. & Nima Forest, Madanpur Range & 5 & 0.910 & 0.567 & 0.566 & 6 & 1.696 & 0.199 & 0.947 & 16 & 2.454 & 0.110 & 0.885 \\
\hline III. & Pirthu Forest, Range Madanpur & 3 & 1.040 & 0.375 & 0.947 & 6 & 1.606 & 0.221 & 0.897 & 14 & 1.541 & 0.319 & 0.584 \\
\hline IV. & Salaya Forest, Madanpur Range & 2 & 0.501 & 0.681 & 0.723 & 8 & 1.638 & 0.228 & 0.788 & 14 & 1.684 & 0.298 & 0.638 \\
\hline V. & Unga Forest, Madanpur Range & - & - & - & - & 11 & 1.812 & 0.222 & 0.756 & 5 & 1.511 & 0.247 & 0.939 \\
\hline VI. & Pathra Beat, Aurangabad Range & 18 & 2.687 & 0.084 & 0.930 & 20 & 2.696 & 0.088 & 0.899 & 24 & 1.955 & 0.290 & 0.616 \\
\hline VII. & $\begin{array}{l}\text { Mahulan, Pathra Beat, Aurangabad } \\
\text { Range }\end{array}$ & 23 & 2.717 & 0.098 & 0.867 & 18 & 2.432 & 0.123 & 0.842 & 29 & 2.442 & 0.167 & 0.726 \\
\hline VIII. & Bheli Bandh, Aurangabad Range & 17 & 1.945 & 0.273 & 0.687 & 10 & 1.918 & 0.189 & 0.833 & 11 & 1.585 & 0.285 & 0.661 \\
\hline IX. & Bhedani, Aurangabad Range & 8 & 1.742 & 0.223 & 0.838 & 11 & 2.062 & 0.166 & 0.860 & 9 & 1.963 & 0.165 & 0.894 \\
\hline $\mathrm{X}$ & Eroura, Aurangabad Range & 8 & 1.667 & 0.256 & 0.802 & 14 & 2.485 & 0.095 & 0.943 & 10 & 1.789 & 0.229 & 0.777 \\
\hline XI. & Bhalwadi Khard, Maharaj Ganj Range & 5 & 0.921 & 0.566 & 0.573 & 10 & 2.103 & 0.138 & 0.914 & 10 & 1.822 & 0.206 & 0.792 \\
\hline XII. & $\begin{array}{l}\text { Peeghliya Forest, Maharaj Ganj } \\
\text { Range }\end{array}$ & 3 & 0.956 & 0.429 & 0.870 & 11 & 2.039 & 0.166 & 0.851 & 16 & 1.831 & 0.233 & 0.661 \\
\hline & ( $\mathrm{SR}=$ Species Richness; H=Diversity & & 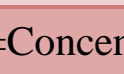 & & 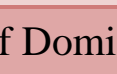 & & & & & & & & \\
\hline
\end{tabular}


Fig.2 Highest Important Value Index (IVI) of tree species in different sites(I: Badam site, II-

Nima Forest III- Pirthu Forest, V: Salaya Forest, V: Unga Forest, VI: Pathra Beat, VII:

Mahulan, Pathra Beat, VIII: Bheli Bandh, IX: Bhedani X: Eroura, XI: Bhalwadi Khard, XII:

Peeghliya Forest)

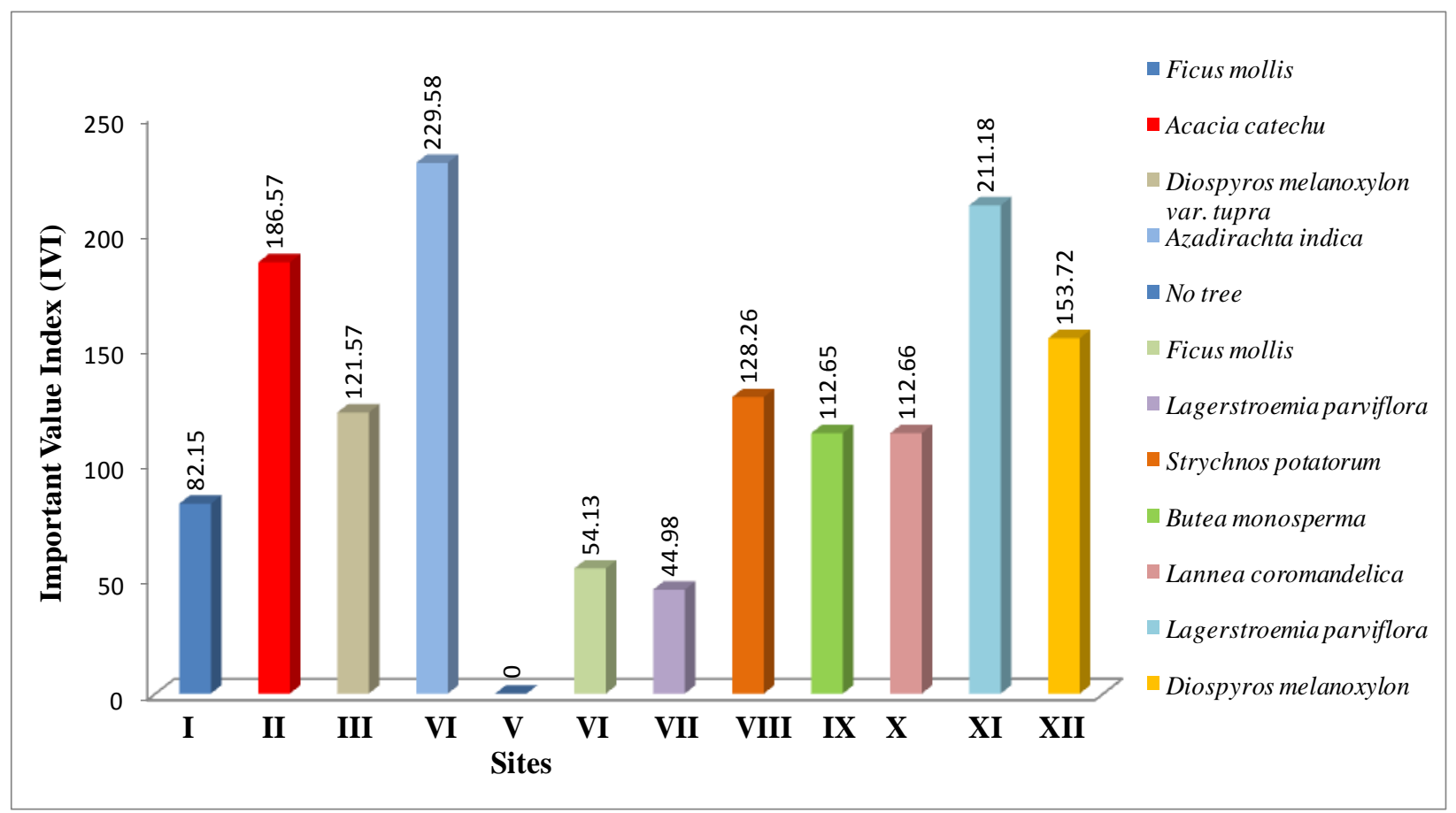

Fig.3 Highest Important Value Index (IVI) of shrubby layer species in different sites

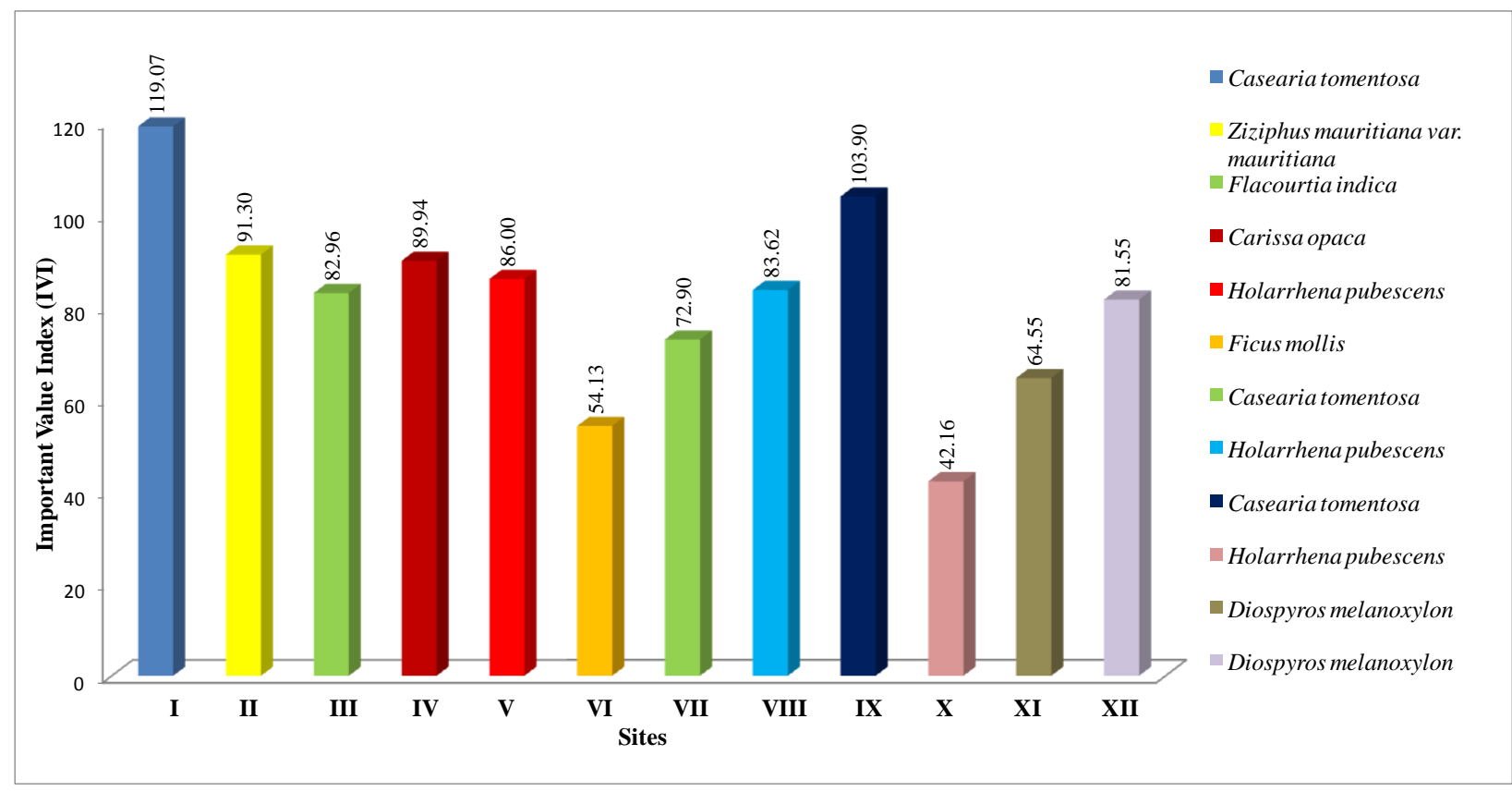


Fig.4 Highest Important Value Index (IVI) of herbaceous layer species in different sites

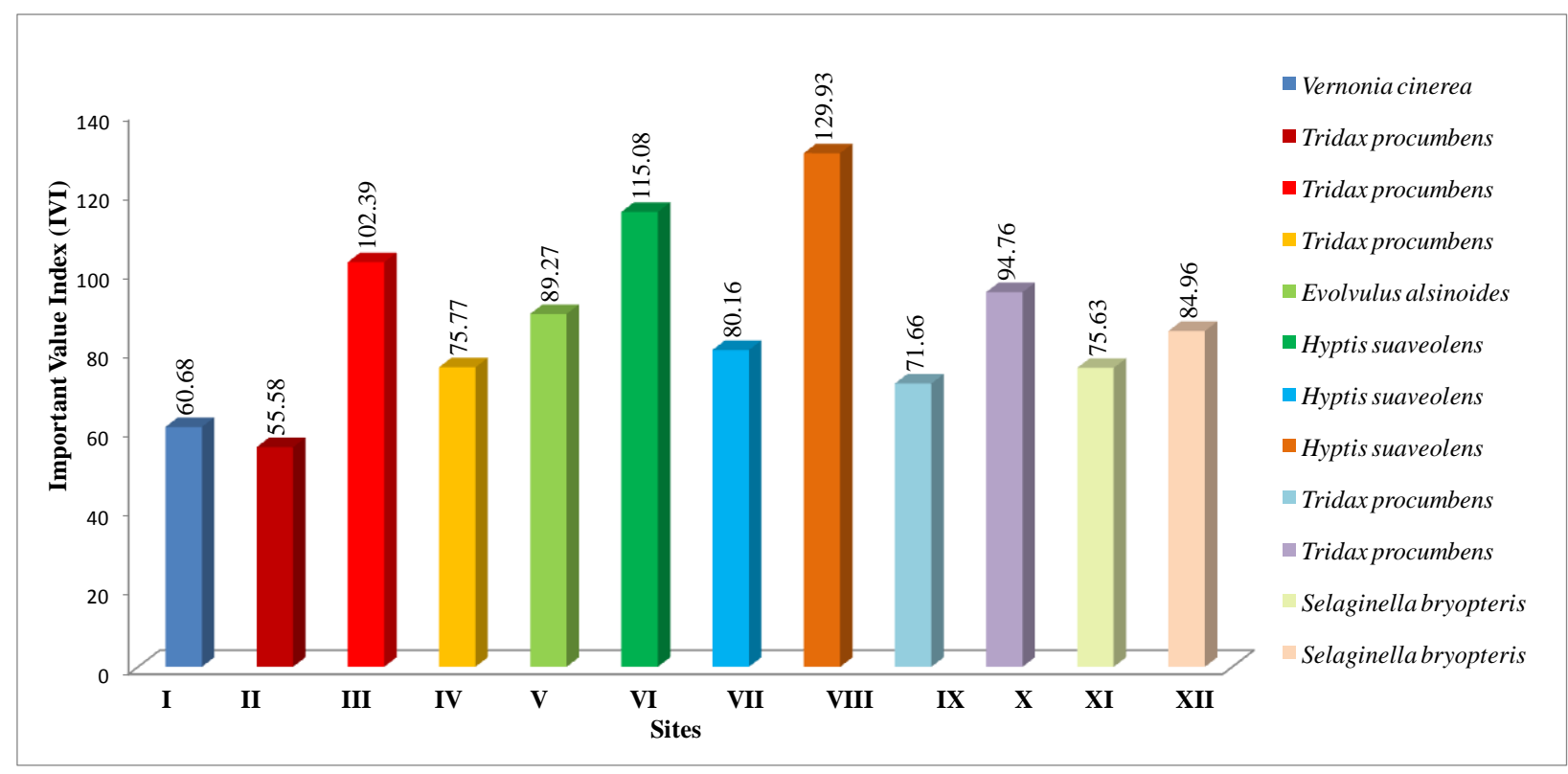

The higher value of Concentration of Dominance (cd), the greater is the homogenous nature of community and viceversa. In other words, such communities are dominant by single species. The lower value of concentration of dominance indicates that dominance of plant is shared by many species. In the tree layer, Concentration of Dominance (cd) was highest in case of Salaya Forest (0.681), followed by Nima Forest (0.567), Bhalwadi Khard (0.566) etc. and lowest in case of Pathra Beat (0.084). Shrubby layer had highest value of Concentration of Dominance (cd) in Badam Forest (0.257), followed by Salaya Forest (0.228), Unga Forest (0.222) etc. and lowest in Eroura(0.095).In the herbaceous layer, highest value of Concentration of Dominance (cd) was estimated for Pirthu Forest (0.319), followed by Salaya Forest (0.298), Pathra Beat (0.290) etc. and lowest in Nima Forest $(0.110)$.

Higher value of Evenness (E) indicates that species are evenly distributed and vice-versa. In case of tree layer, highest Evenness (E) value was estimated for Badam Forest site (1.107), followed by Pirthu Forest (0.947), Pathra Beat (0.930) etc. and lowest in Nima
Forest (0.566). In case of shrubby layer, highest Evenness (E) value was recorded for Nima Forest (0.947), followed by Eroura (0.943), Bhalwadi Khard (0.914) etc. and lowest in Unga Forest (0.756). In the herbaceous layer, highest value of Evenness (E) was estimated for Unga Forest (0.939), followed by Bhedani (0.894), Nima Forest (0.885) etc. and lowest in Badam (0.216).

It reveals from the study that Mahulan and pathra forest sites are more diverse site in the Aurangabad forest division. Study also reveals that Lantana camara var. aculeata an invasive is showing its presence in the area, it can adversely impact the indigenous species in future. Both quantitative and quantitative assessment of vegetation is essential for developing conservation and management strategies. Hence, presence study will be immense use for the field staff of the forest department for making future working plans. Regular inventorization and monitoring of plant diversity is the need of the hour. Therefore, similar kind of studies should be carried out in different forest sites to assess the present status of plant diversity for conservation and sustainable management. 


\section{Acknowledgement}

Authors are thankful to the Director, Forest Research Institute, Dehradun for constant encouragement and support. Authors are also thankful to the PCCF and other Forest officials of Bihar Forest Department for funding and proving necessary support for carrying out the study.

\section{References}

Anderson, T. 1863. On the Flora of Bihar and the mountains of Parasnath with a list of species collected by Messrs Hooer, $J$. Asiat. Soc., Bengal. 32:187-218.

Bhatacharya P. K. and Sarkar K. 1998. Flora of West-Champaran District, Bihar. Botanical Survey of India, Calcutta.

Billings, W.D. 1952. The environment complex in relation to plant growth and distribution Quarterly Review of Biology. 27; 251265.

Biswas, D. K. and Maheshwari, J. K. 1980. A contribution to the vegetation of Chaibasa, Singhbhum District in South Bihar. Bull. Bot. Soc. Bengal 25 (1 \& 2): 43-51.

Braun Blanquet, J. 1932. Plant Sociology :the study of plant communities. McGrawHill, New York.

Forest Survey of India. 2019. State of Forest Report. Forest Survey of India. Dehradun

Haines, H.H. 1921-24. The Botany of Bihar and Orissa. Adlard and Sons, London.

Hooker, J.D. 1875-1897. The Flora of British India (7 Vols.). L. Reeve and Co., London.

Knight, D.H. 1963. A distance method for constructing forest profile diagrams and obtaining structural data. Tro. Ecology. 89-94.

Misra, R. 1968. Ecological Workbook. Oxford Press, New Delhi.

\section{How to cite this article:}

Chandra, A., H. B. Naithani, P. K. Verma, J. Saxena, R. Saini and Kishwan, S. 2021. Assessment of Plant Diversity of Selected Forest Sites of Aurangabad District of Bihar. Int.J.Curr.Microbiol.App.Sci. 10(02): 462-468. doi: https://doi.org/10.20546/ijcmas.2021.1002.054
Mooney, H.F. 1950. Supplement to the Botany of Bihar and Orissa. Catholic Press, Ranchi.

Mukherjee, S.K. 1947. A Botanical Tour in Chhotanagpur. Bull. Bot. Soc. Bengal 1:27-28.

Odum, E.P. 1971. Fundamentals of Ecology (Third Ed). W.B. Saunders, Philadelphia

Paul, S.R. 1973. On the aquatic and Marsh Flora of Monghyr, Bihar. Botanique : 143-152.

Pielou, E.C. 1966. The measurement of diversity in different types of biological collections. Journal of Theoretical Biology, 13, 131144.

Ralhan, P.K., Saxena, A. K. and Singh, J. S. 1982. Analysis of forest vegetation at and around Nainital in Kumaun Himalaya. Proc. Indian National Sciences.19:307324.

Resser, P.G. and Rice, E.L. 1971. Diversity in tree species in Oklahoma upland forests. Ecology. 52:876-880.

Shannon, C. E. and Wiener, W. 1963. The Mathematical Theory of Communities. University of Illinois press, Urbana, 117.

Simpson, E. M. 1949. Measurement of diversity. Nature, 163: 688.

Singh, N.P., Mudgal V., Khanna K.K, Srivastava S.C., Sahoo A. K., Bandhopadhay S., Aziz N., Das M., Bhattacharya R.P. and Hajra P.K.. 2001. Flora of Bihar-Analysis. Botanical Survey of India, Calcutta

Whittakar, R.H. 1965. Dominance and diversity inland plant communities: numerical relations of species express in importance of competition in community function and

Wood, J. J. 1903. Plants of Chotanagpur including Jaspur and Surguza. Rec. Bot. Sur. India. 2:1-170. evolution. Science, 147 (3655), 250-260. 